\title{
Notes on misconceptions in the application of geographical names of the tepuis on the borderlands of Guyana and Venezuela and a clarification of the location of Waukauyengtipu and Cerro Venamo
}

\section{Abstract}

A review of recent publications concerning the South American Pantepui biogeographic region revealed recurring mistakes in the naming of several table mountains (known locally as 'tepui', 'tipu' or 'tepuy') located around the Guyana-Venezuela border, close to the transection of the so-called Schomburgk Line and the course of Rio Venamo. The mistakes are believed to have arisen and have been repeated as a result of a noticeable scarcity of detailed maps of the region, its short history of exploration and ongoing inaccessibility.

An extensive analysis of modern satellite data and records of past research expeditions, supplemented by first-hand observations and assessment made during an expedition to Waukauyengtipu in the CuyuniMazaruni Region in Guyana in January 2019, are used to clarify the nomenclatural confusion regarding the tepuis of the area. We determine that the tepuis known as Cerro Venamo and Waukauyengtipu should be treated as separate and distinct geographic formations.

Keywords

Guiana Highlands • Waukauyengtipu • Tepui • Cerro Venamo • Guiana Shield $\cdot$ Guayana

\author{
Mateusz Wrazidlo: ${ }^{1}$, \\ Stewart McPherson², \\ H. David Clarke ${ }^{3}$, \\ 'Department of Fundamentals of Machinery Design, \\ Faculty of Mechanical Engineering, Silesian University \\ of Technology, Gliwice, Poland \\ e-mail:matwraz@gmail.com \\ ${ }^{2}$ Redfern Natural History Productions Ltd. \\ 61 Lake Drive, Hamworthy, Poole, Dorset, \\ United Kingdom \\ e-mail: stewart@mcpherson.net \\ ${ }^{3}$ Department of Biology, The University \\ of North Carolina Asheville, One University Heights, \\ Asheville, USA \\ e-mail: dclarke@unca.edu \\ Received: 15 March 2021 \\ Accepted: 27 October 2021
}

\section{Introduction}

An expedition to the territory of Paruima in the CuyuniMazaruni Region in Guyana, belonging to the Pemón Arekuna indigenous community was organized between January $3^{\text {rd }}$ $12^{\text {th }}, 2019$. The objective of the expedition was to visit the poorlydocumented section of Gran Sabana (Eng. - "Great Savanna") that lies around the Uchi Fall in Guyana (also known as Uchii Falls, Utschi Falls, Oshi Falls), beyond Venezuela's easternmost borders, and to attempt to ascend and explore the summit of Waukauyengtipu.

Interviews with local, indigenous inhabitants of the area undertaken during that expedition and subsequent research of the literature have established continuing inaccuracies concerning the naming of Waukauyengtipu in Guyana, and also Cerro Venamo, located nearby in Venezuela.

\section{"White spots" on the map in the $21^{\text {st }}$ century}

Cerro Venamo is a relatively small tepui situated close to the western border of Guyana, marked by the course of Rio Venamo (also known as Wenamu River or Venamo River) (Anderson 2003) and the northwestern end of the so-called Schomburgk Line - a name used for the southwestern part of the Guyana-Venezuela border between the presumed westernmost source of Rio Venamo ( $5^{\circ} 56^{\prime}$ 55.4" N, 61 ${ }^{\circ} 23^{\prime} 24.7^{\prime \prime} \mathrm{W}$ ) and the Tripoint Marker on the summit of Mount Roraima ( $5^{\circ} 12^{\prime} 08.6^{\prime \prime} \mathrm{N}, 60^{\circ} 44^{\prime} 07.5^{\prime \prime}$ W) (Department of State 1963) (Fig. 1). Its massif is mostly within the Venezuelan territory, near the $115^{\text {th }}$ kilometre of the Venezuelan Troncal 10 road. Cerro Venamo straddles the border of the two countries and its southwestern slopes form the westernmost part of Guyana, as verified by modern satellite imagery.
The recorded history of exploration of Cerro Venamo is not extensive, with the most notable event being a botanical expedition organized by J.A. Steyermark and G. Dunsterville between December 1963 and January 1964 (Robinson 1965). A review of herbarium material (NY) collected by Steyermark \& Dunsterville revealed that the location and elevation of Cerro Venamo is $5^{\circ} 59^{\prime} \mathrm{N}, 61^{\circ} 23^{\prime} \mathrm{W}, 1890 \mathrm{~m}$ a.s.l. (Dauphin \& Ilkiu-Borges 2002), although an analysis of digital elevation data available in Google Earth (Google Earth 2021), which was proven to provide good correlation with ASTER (Advanced Space-borne Thermal Emission and Reflection Radiometer) and SRTM (Shuttle Radar Topography Mission) elevation data (Rusli et al. 2014), reveals that the actual elevation of the plateau reaches approx. $1420 \mathrm{~m}$ a.s.I., with some more elevated areas sharing the same base formation visible in its vicinities.

Additional information about the location of Cerro Venamo can be found in entomological papers and confirmed by locations marked on scorpion specimens collected in the area (Rojas-Runjaic \& Sousa 2007), namely Vachoniochactas lasallei and Neochactas efreni (González-Sponga 1978). Their type localities are marked consecutively as "Cerro Venamo, carretera EI Dorado-Santa Elena de Uairén, Km. 126, Edo. Bolívar. Altura: 1320 metros" for V. lasallei and "Cerro Venamo, kilómetro 115, en la carretera EI Dorado-Santa Elena de Uairén, Edo. Bolívar. Alt.: 960 m" for $N$. efreni. Based on interviews made by the lead author, German botanical expeditions were undertaken during the late 1990s and early 2000s in the vicinities of Cerro Venamo using a helicopter with scattered landing locations, although a full account of the findings of these expeditions has not been formally published. 


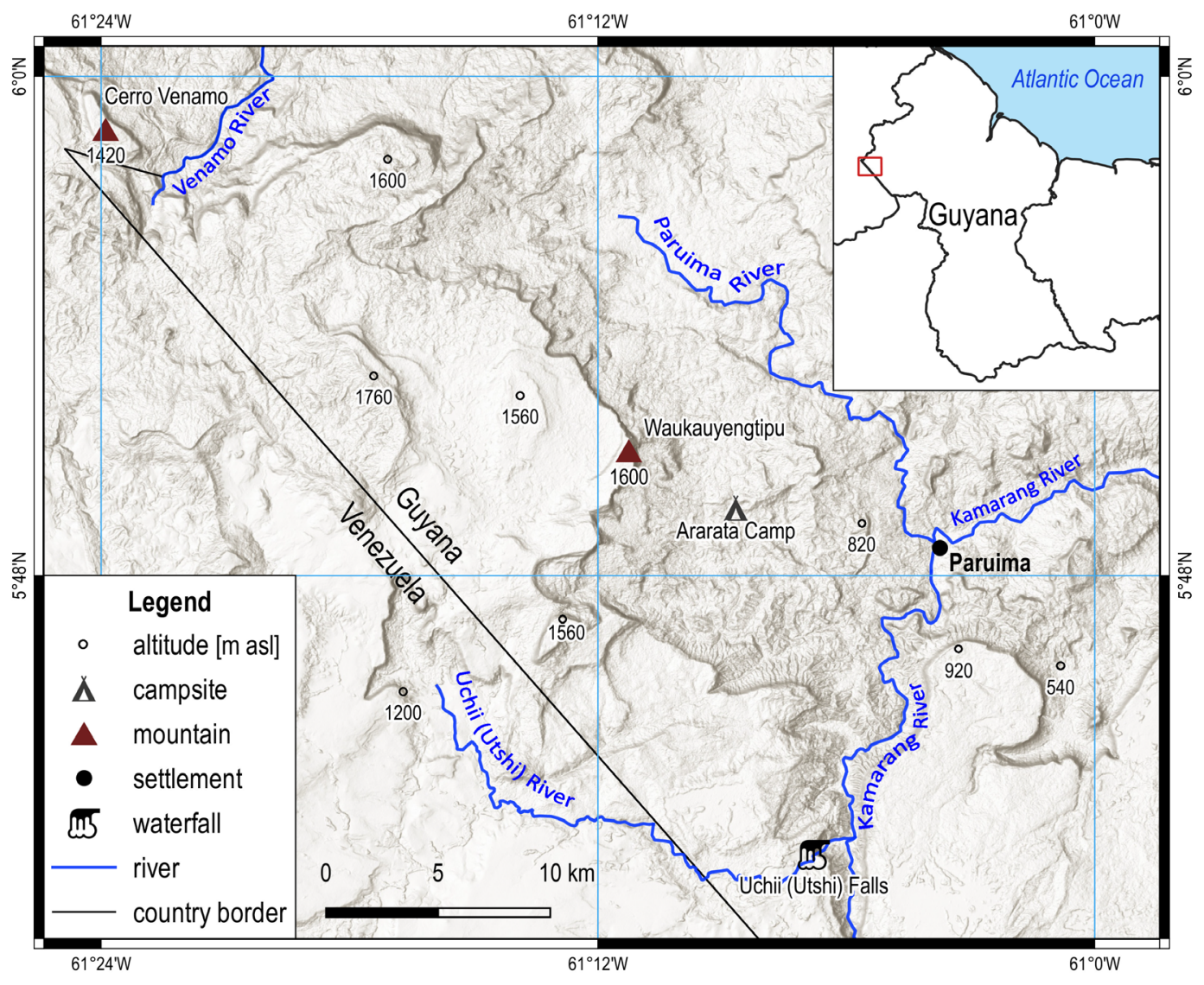

Figure 1. Exploration history. A map presenting the location of recorded expeditions to Cerro Venamo (Steyermark \& Dunsterville 1963/64) and Waukauyengtipu (Clarke 1997; Wrazidlo \& Carpenay 2019)

Source: map by Łukasz Fiedeń, Jagiellonian University. Made with QGIS (QGIS 2021)

Waukauyengtipu is also a tepui in Guyana, close to the Venezuelan border. The elevation of Waukauyengtipu reaches approx. $1520-1600 \mathrm{~m}$ a.s. I in its easternmost reaches $\left(5^{\circ} 51^{\prime} 00^{\prime \prime} \mathrm{N}\right.$, $\left.61^{\circ} 11^{\prime} 15^{\prime \prime} \mathrm{W}\right)$, as indicated by satellite imagery and elevation data provided by Google Earth (Google Earth 2021) and verified by GPS altitude readings recorded by the team of the 2019 expedition. The eastern slopes are situated west of the Pemón Arekuna community of Paruima, in Region 7, Cuyuni-Mazaruni, Guyana. The name Waukauyengtipu means "mountain of the place of a butterfly" in the Pemón Arekuna language ('tipu' being equivalent, used commonly in Guyana, to the name 'tepui'). It was first ascended by a Smithsonian team led by $\mathrm{H}$. David Clarke, the co-author of this paper, in 1997 (Kelloff et al. 2011). The second recorded summiting took place in January 2019 and was coorganized by the first author of this paper and Darrell Carpenay, a Guyanese photographer, guided by a group of members of the Pemón Arekuna community of Paruima (Wrazidlo 2021). No records exist confirming any successful ascents of Waukauyengtipu from the western side.

The eastern, southeastern and northeastern sides of the mountain are defined by steep cliffs, giving it a classic tepui profile (rectangular mountain cross section) (Fig 2). The massif transitions into a less well-defined system of slopes on the westward side towards the Venezuelan border, in some places forming fragmented elevated areas visible in the satellite imagery. Some of those elevated features are mentioned in the Gazetteer of Guyana as separate mountains - namely Wokarapang Mountain ( $\left.5^{\circ} 54^{\prime} 48^{\prime \prime} \mathrm{N}, 61^{\circ} 16^{\prime} 5^{\prime \prime} \mathrm{W}\right)$, Waikaweak
Mountain $\left(5^{\circ} 53^{\prime} 44^{\prime \prime} \mathrm{N}, 61^{\circ} 18^{\prime} 1^{\prime \prime} \mathrm{W}\right)$ and Kanaimatipu Mountain $\left(5^{\circ}\right.$ $\left.57^{\prime} 36^{\prime \prime} \mathrm{N}, 61^{\circ} 17^{\prime} 17^{\prime \prime} \mathrm{W}\right)$ (Digital Online Gazetteer of Guyana 2021). Due to the lack of a distinct, steep escarpment on the side facing the territory of Venezuela, it is difficult to define the precise area of the summit of Waukauyengtipu.

Past publications are highly inconsistent with regards to the names applied to Cerro Venamo and Waukauyengtipu. The names of both mountains are incorrectly used interchangeably in many recent publications (Rull \& Vegas-Vilarrúbia 2020), (Rull et al. 2019) and also in online sources (Rice 2018). In addition, the name Waukauyengtipu does not appear in the Gazetteer of Guyana, which is the official directory of place names within Guyana (Digital Online Gazetteer of Guyana 2021), despite being mentioned in numerous other sources and known by the indigenous inhabitants in the area. Some had erroneously suggested that Cerro Venamo and Waukauyengtipu are in fact one and the same mountain which simply had two different names, although this is certainly not the case. Such an assertion is not precise and might result in the spread of further confusion and inaccuracies in future scientific work focused on the area.

Other than satellite imagery and other forms of remote sensing data, very few accurate maps of this area exist, and this is especially true of highly- detailed maps showing smaller geographic features and their names, such as the two mountains in question here. Indeed, much of the remote uplands along the northwestern end of the Guyana-Venezuela border, marked by the so-called Schomburgk Line, remain incompletely explored (Huber 1995a). 


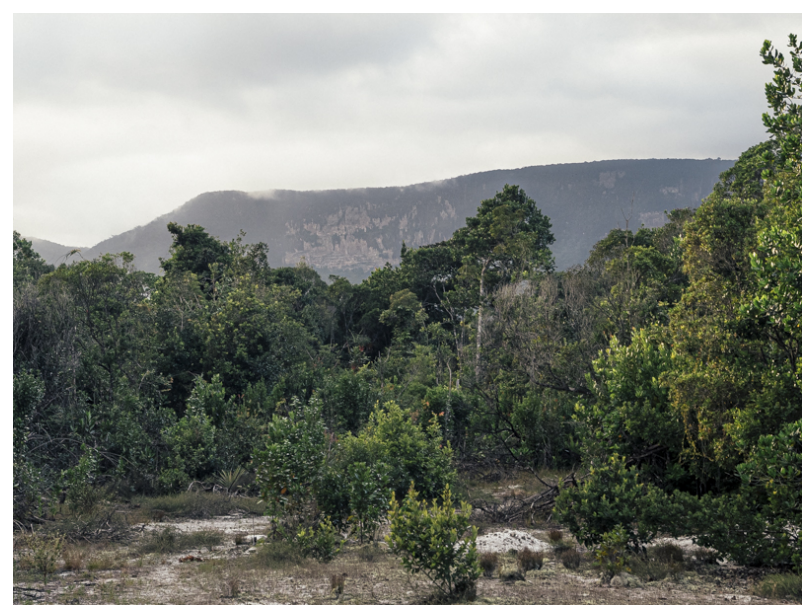

Figure 2. Eastern wall of Waukauyengtipu. Seen from Ararata Camp, Guyana, 549'37.4"N 61 $08^{\prime} 38.7^{\prime \prime} W$

Photo by: Mateusz Wrazidlo

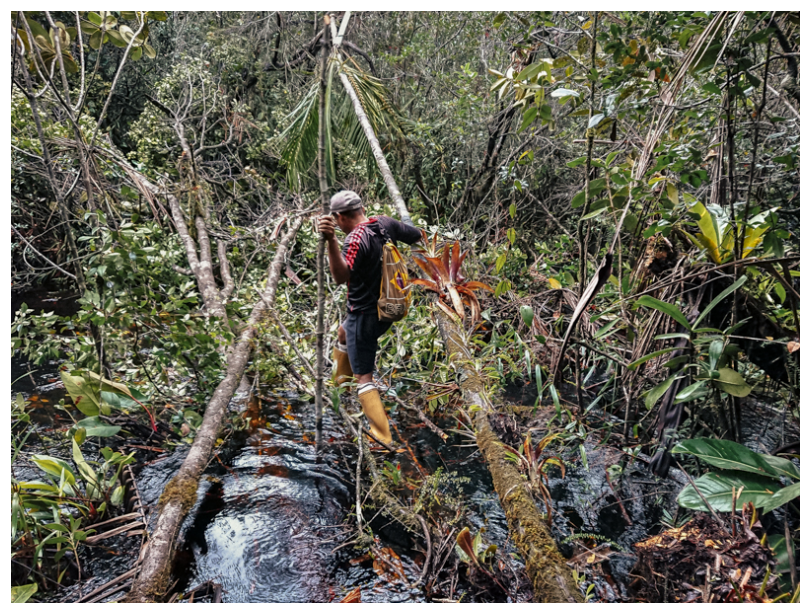

Figure 3. Wetlands on the summit of Waukauyengtipu. Calio Elliman, of the Arekuna community of Paruima, crossing the submerged swampland on the summit plateau of Waukauyengtipu

Photo by: Mateusz Wrazidlo

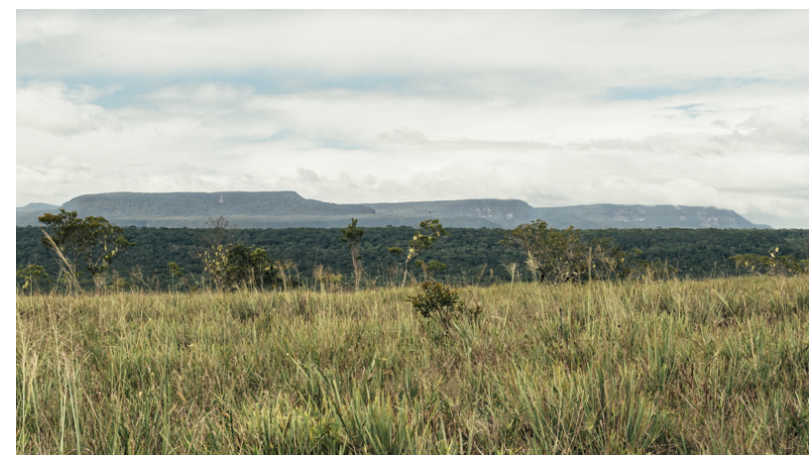

Figure 4. Waukauyengtipu. Waukauyengtipu plateau seen from the savanna in close proximity to Uchi Fall, Guyana, $5^{\circ} 40^{\prime} 21^{\prime \prime} \mathrm{N}$ $61^{\circ} 07^{\prime} 24^{\prime \prime} W$

Photo by: Mateusz Wrazidlo
Exploration of the area is very difficult due to its remoteness and the hazardous nature of the local environment. The team of the 2019 Waukauyengtipu expedition noticed that most of the summit plateau is comprised of a cloud forest that is extremely difficult and laborious to penetrate, interspersed with large patches of partially-submerged swamplands which render the area exceptionally challenging to cross on foot and mostly unsuitable for helicopter landings (Fig 3).

Waukauyengtipu and Cerro Venamo are part of a larger upland feature situated at the point where the Sierra de Lema and the Roraima-llu tepui ranges meet, along the VenezuelaGuyana border (Huber 1995b).

\section{Location of Waukauyengtipu and Cerro Venamo}

The publication of this paper is intended formally to clarify the location and correct naming of Waukauyengtipu and Cerro Venamo.

Waukauyengtipu and Cerro Venamo are separate plateaus, as verified by coordinates noted on H.D. Clarke's herbarium specimens and concluded from the Cerro Venamo botanical and entomological collections of J.A. Steyermark and M.A. GonzálezSponga, as well as GPS data obtained on Waukauyengtipu during the 2019 expedition (Fig. 1). Waukauyengtipu is situated approximately $27 \mathrm{~km}$ southeast of Cerro Venamo. Waukauyengtipu is also clearly discernible across stretches of upland savanna in the vicinity of Uchi Fall in Guyana ( $5^{\circ} 40^{\prime} 21^{\prime \prime} \mathrm{N}$ $\left.61^{\circ} 07^{\prime} 24^{\prime \prime} \mathrm{W}\right)$, as shown in Fig. 4 below.

The names used in this paper were confirmed as correct during a field assessment in Guyana in January 2019. Field observations and interviews with members of the local Pemón Arekuna community in Paruima and its surrounding areas were used to affirm the terminology used here.

The fact that Waukauyengtipu and Cerro Venamo share a common base structure should not negate the reality that each feature has a distinct name, used by indigenous communities in the area, and as such, each should be recognized by their respective, separate names.

This is precisely the case for many other tepuis, for example, Ptari massif, a small mountain system consisting of three plateaus located north of the Santa Teresita de Kavanayén mission in Gran Sabana, Venezuela, relatively close by, southwest of the Cerro Venamo massif. In this example, all three plateaus are part of a single, shared upland base structure, but each is consistently treated as a separate geographic feature in modern literature and named accordingly; Ptari-tepui, Sororopán-tepui and Carraotepui (Huber 1995c).

It should be noted that, across the entire region, local communities used distinct, indigenous names to refer to each tepui, including all of the features mentioned in this paper. These names were mostly used by European and North American explorers over the last two centuries, and many remain as the commonly-recognized toponyms of the region (McPherson 2008). The opinion of the local indigenous communities is of the highest significance in this case and respecting the traditional nomenclature serves to preserve and popularize the precious cultural heritage of the entire area of the Guiana Highlands.

\section{Conclusions}

Waukauyengtipu and Cerro Venamo may be relatively small geographical features that are overshadowed by much larger and more famous mountains in the region (e.g. Mount Roraima, Auyán-tepui, Macizo del Chimantá etc.), but they are no less interesting, since both remain poorly-known to this day, especially in terms of the biodiversity that they harbour.

The fact that even the names of these two tepuis remain confused is testimony to how little we actually know about 
either of them. A series of expeditions, led on foot, to explore Waukauyengtipu and Cerro Venamo represents the only realistic way to fully survey their botany and zoology and to understand their topography in great detail at a scale which satellite data cannot provide. It will likely be many years before Waukauyengtipu and Cerro Venamo are fully explored, but the authors hope that this paper may succeed at least in clarifying the nomenclature of these interesting plateaus for the benefit of future attempts.

Taking into consideration the complexity and extensiveness of the entire Cerro Venamo-Waukauyengtipu mountainous structure, better data needs to be disseminated for future research and explorations. To avoid the further spread of confusing information, the authors suggest that more detailed geographical surveying work needs to be undertaken in the area. Using a combination of aerial photography, satellite imagery and fieldwork on the ground, it will be possible to uncover fully the extent and geography of both features and, if needed, to assess the geographical terminology concerning other prominent formations within the range, acting in accordance with the standardization principles defined by the United Nations. As confirmed by the UN Manual for the national standardization of geographical names (United Nations 2006), field collection of locally used names, which are often only maintained in oral tradition, preserves local knowledge and parts of the region's heritage. If undertaken in collaboration and consultation with the local indigenous communities, such endeavours will serve to improve the understanding of the geography of the fascinating region of the Guiana Highlands, as well as to support and popularize its unique indigenous heritage.

\section{Acknowledgements}

We sincerely thank all the members of the Pemón Arekuna community of Paruima, especially Calio Elliman, Chris Elliman, Alex Smith, Lee Williams and Lennox Percy for their assistance and guidance during the January 2019 expedition to Waukauyengtipu. Łukasz Fiedeń is acknowledged for preparing the map for Figure 1. Krzysztof Gwosdz, Otto Huber and Jarosław Balon are thanked for providing useful recommendations and commentary. Special thanks go to the team members of the 2019 Waukauyengtipu expedition: Darrell Carpenay for helping with the organization of the expedition, Orson Hinds for sharing his culinary skills which helped lift the spirits in the harsh conditions on Waukauyengtipu and Izabela Stachowicz for participating in the project and sharing her knowledge. Other members, helpers and advisers who took part in the successful conclusion of the expedition in Guyana, especially Andrew Snyder and Karen Redden are thanked for their help and commitment. We would also like to acknowledge the Silesian University of Technology for providing financial support for the 2019 Waukauyengtipu expedition.

\section{Special dedication}

I would like to dedicate this work to my beloved brother, Jakub Wrazidlo, (26.04.2004 - 27.10.2021) who gave me the courage and motivation to explore the last frontiers of wilderness in our world and made me the person I am today.

Mateusz Wrazidlo

\section{ORCID}

Mateusz Wrazidlo (D) https://orcid.org/0000-0001-5383-1906

\section{References}

Anderson, EW 2003, International boundaries: a geopolitical atlas, Routledge, New York.

Dauphin, G \& Ilkiu-Borges, AL 2002, 'Hepaticae of Cerro Venamo, Venezuela, collected by J. Steyermark', Bryophyte Diversity and Evolution, vol. 22, no. 1, pp. 115-123.

Digital Online Gazetteer of Guyana 2021, Guyana Lands and Surveys Commission. Available from: <https://gazetteer. glsc.gov.gy>. [29 July 2021]

Google Earth 9.142.0.1 2021. Available from: <https://earth. google.com/web/>. [29 July 2021].

González-Sponga, MA 1978, Escorpiofauna de la Región Oriental del Estado Bolívar, en Venezuela [Scorpiofauna of the Eastern Region of Estado Bolívar, in Venezuela], RotoImpresos, Caracas, Venezuela.

Huber, O 1995a, 'Geography and physical features' in Flora of the Venezuelan Guayana. Volume 1. Introduction, eds JA Steyermark, PE Berry \& BK Holst, Missouri Botanical Garden, Timber Press, St. Louis, pp. 1-61.

Huber, O 1995b, 'History of botanical exploration' in Flora of the Venezuelan Guayana. Volume 1. Introduction, eds JA Steyermark, PE Berry \& BK Holst, Missouri Botanical Garden, Timber Press, St. Louis, pp. 63-95.

Huber, O 1995c, 'Conservation of the Venezuelan Guayana' in Flora of the Venezuelan Guayana. Volume 1. Introduction, eds JA Steyermark, PE Berry \& BK Holst, Missouri Botanical Garden, Timber Press, St. Louis, pp. 193-208.

Department of State 1963, 'Guyana (British Guiana) Venezuela Boundary', International Boundary Study No. 21, Office of the Geographer, Bureau of Intelligence and Research, Department of State, Washington D.C. Available from: <https://fall.fsulawrc.com/collection/LimitsinSeas/ numericalibs.html>. [29 July 2021].
Kelloff, CL, Alexander, SN, Funk, VA \& Clarke, HD 2011 'Smithsonian Plant Collections, Guyana: 1995-2004, H. David Clarke', Smithsonian Contributions to Botany, vol. 97, pp. 44-46.

McPherson, S 2008, Lost worlds of the Guiana Highlands, Redfern Natural History Productions Ltd., Poole, Dorset.

QGIS 2021, QGIS Geographic Information System, Open Source Geospatial Foundation Project. QGIS Development Team. Available from: <http://qgis.osgeo.org>. [04 March 2021].

Rice, B 2018, 'Heliamphora: the various ranges and tepuis', The Carnivorous Plant FAQ, vol. 12. Available from: <http://www. sarracenia.com/faq/faq5365.html>. [12 May 2020].

Robinson, H 1965, 'Venezuelan bryophytes collected by Julian A. Steyermark', Acta Botánica Venezuélica, vol. 1, no. 1, pp. 73-83.

Rojas-Runjaic, F \& Sousa, L 2007, 'Catálogo de los escorpiones de Venezuela (Arachnida: Scorpiones)' ['Catalog of scorpions of Venezuela (Arachnida: Scorpiones)'] Boletín de la Sociedad Entomológica Aragonesa, vol. 40, pp. 293-297.

Rull, V \& Vegas-Vilarrúbia, T 2020, 'The Pantepui "Lost World": Towards a biogeographical, ecological and evolutionary synthesis of a Pristine Neotropical Sky-Island Archipelago in Neotropical Diversification: Patterns and Processes, eds V Rull \& AC Carnaval, Springer International Publishing, pp. 369-413, Cham.

Rull, V, Huber, O, Vegas-Vilarrúbia, T \& Señaris, C 2019, 'Definition and characterization of the Pantepui biogeographical province' in Biodiversity of Pantepui, eds $\vee$ Rull, T VegasVilarrúbia, O Huber \& C Señaris, Academic Press, pp. 3-32, Cambridge.

Rusli, N, Majid, MR \& Din, AHM 2014, 'Google Earth's derived digital elevation model: A comparative assessment with 
Aster and SRTM data', IOP Conference Series: Earth and Environmental Science, vol. 18.

United Nations 2006, Manual for the national standardization of geographical names. United Nations Group of Experts on Geographical Names, Department of Economic and Social Affairs Statistics Division, New York. Available from: <https:// unstats.un.org/unsd/publication/seriesm/seriesm_88e.pdf>. [25 July 2021].

Wrazidlo, M 2021, 'Waukauyengtipu and Uchii River Uplands Expedition 2019 - report with photographic observations of carnivorous flora of the Paruima territory in the CuyuniMazaruni Region of Guyana', Carnivorous Plant Newsletter, vol. 50, no. 3, pp. 141-152. Available from: <https://cpn. carnivorousplants.org/Article.php/CPNv50n3>. 